\title{
Effect and Technique of Danda Dhauti
}

\author{
SK Ganguly* \\ G S College of Yoga \& C S Kaivalyadhām, India
}

Submission: November 16, 2018; Published: April 01, 2019

*Corresponding author: SK Ganguly, G S College of Yoga \& C S Kaivalyadhām, Lonavla, India

Keywords: Sadhana kriyas; Nadim siddhi; Ghatam suddhi; Mala siddhi; Prana siddhi; Siddhi kriyas; Gheada samhita; Ghatam; Danda dhauti; Hrddhauti; phlegm; Hypertension; Insomnia; Hyperacidity; Chronic cold; cough

\section{Introduction}

Yogic cleansing processes are getting slowly good importance as a therapy in the treatment of Asthma [1,2]. Hypertension, Insomnia, Hyperacidity, and Chronic cold \& cough and various other malfunctions of the organic systems of human being. These are often called as Six (Sathe) Kriyas or Karmas, or Sadhana Kriyas, or Siddhi Kriyas for Nadim Siddhi, Ghatam Suddhi, Mala
Siddhi, Prana Siddhi, and later on Chita Siddhi. They work at different levels in different Kriyas. Initially they do de-condition the wrong habits and recondition the internal systems. This idea is brought out in one of the traditional texts of Yoga, Gheada Samhita [3]. Gheada muni says about Seven objectives of yoga to take care of individual physical body (Ghatam) They are achieved by practicing respectively: (Figure 1).

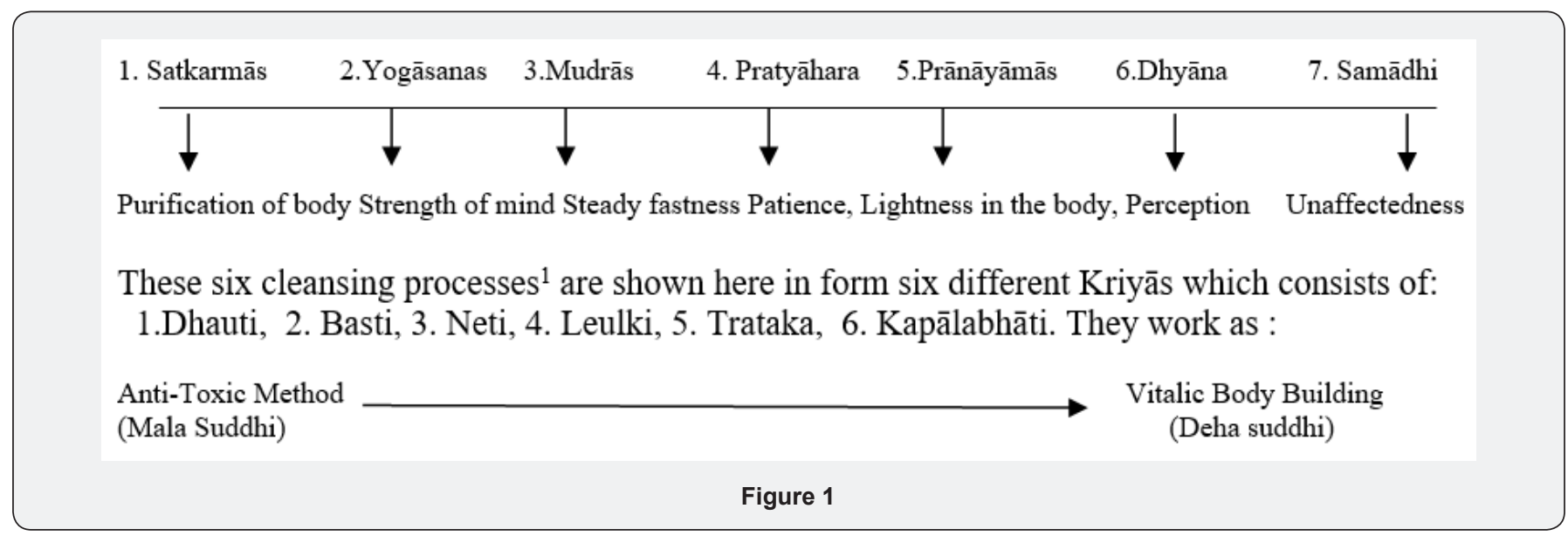

Hatha Pradipika mentions the utility of these six cleansing processes even to get rid of corpulence, disorders of phlegm and other impurities. Dhauti being the first one, let us have some idea about Danda Dhauti techniques and its advantages. There are four dhautis which come under Hrddhauti. Danda Dhauti is one of them and is a combination of two words namely "Danda" and "Dhauti" meaning a stalk and to clean respectively. The root

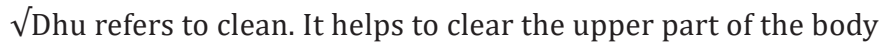
above the naval region. The traditional text, Gheranda Samhita [3] says:

$$
\begin{aligned}
& \text { jEHkkn.Ma gfjn n.Ma os=kn.Ma rFkSo p A } \\
& \text { g`Ue/; s pkyf;Rok rq iqu\% izR;kgjsPNuS\% AA 1/4 G.S.:1:361/2 }
\end{aligned}
$$

It means that one must move a plantain or a turmeric stalk or a cane stalk in the mouth and slowly drawn in and out for taking out the phlegm, bile and also other impurities through the mouth. In the orthodox system, the above things were used as the "Dandi". They were specially prepared before use. They were smoothened in one end and made into fine brush by chewing it and finally cleaned. It was then passed through the food pipe with a swallowing action and gently taken out from the mouth. During these processes, all the internal contents were taken out with reflex action. But in this modern age, the process including the "Dandi" is modified. Swami Kalayaan developed this for the first time to use the rubber tube as dana which can be sterilized in boiling water. 


\section{Journal of Yoga and Physiotherapy}

\section{Technique}

An Indian rubber tube of about $90 \mathrm{cms}$. long and of $0.5 \mathrm{cms}$. in bore is used in place of these stalks. The ends of soft rubber tube are rubbed on the sand paper or on a stone to make it smooth so as to reduce the pricking sensation at the mouth while inserting it. Before it is used it is boiled for 5 minutes in a pan containing water. The water may be mixed, with a little common salt. After making the water little cool, the "Dandi" is taken out and a few glasses of water from the same water are taken in. The tube is passed through the mouth slowly with a swallowing action right up to its $3 / 4$ length and the remaining $1 / 4$ of its length approximately is kept out of the mouth and is being held by the hands. Initially the whole part of the tube may or may not be taken in by a beginner. It may take 15 to 20 days and even more depending on the nature of personality. Once the tube is taken in, the practitioner bends forward a little so that the level of inside tube end remains in a greater height than the outside tube end. One then starts inhaling and exhaling from the nostril for a few seconds. These actions help to bring out the water along with other mucus and impurities based on symphonic principle. This completes the technique of Dandi Dhatu with the Indian rubber tube [4].

There are certain salient points, which are to be kept in mind before one goes for Dandi Dhatu practice. Dos and Don'ts (Table 1).

Table 1

\begin{tabular}{|c|c|}
\hline \multicolumn{1}{|c|}{ Do's } & Don'ts \\
\hline $\begin{array}{c}\text { 1. Ends of Danda must be mades mooth by rubbing it on sand } \\
\text { smooth by rubbing it on sand paper or on a stone. }\end{array}$ & 1. Do not use the tube of others. \\
\hline 2. Boil the tube before use for about 4 to 5 minutes. & 2. Do not face the sun while doing it. \\
\hline $\begin{array}{c}\text { 3. While inserting the tube into. the food pipe, action should be } \\
\text { slow and smooth }\end{array}$ & $\begin{array}{c}\text { 3. Do not pull out the tube forcibly If there is a catch in the mouth, don't } \\
\text { panic, try to have few normal breathing\& have some cups of water \& then } \\
\text { try to take out slowly. }\end{array}$ \\
\hline $\begin{array}{c}\text { 4. To bring out water, inhale and exhale a few times and pull the } \\
\text { s. Practice Pranayama after this1 It will be profitable. }\end{array}$ & $\begin{array}{c}\text { 4. Don't do Danda dhauti daily. Have a gap of } 1 \text { or } 2 \text { days between the } \\
\text { practice or when needed1 }\end{array}$ \\
\hline 6. The Danda must be kept clean abdominal before and after use. & 6.Do not practice it with heart trouble, abdominal before and after use. \\
\hline
\end{tabular}

\section{Research Findings and Benefits}

It helps to have control over autonomic and proprioceptor Neuro-muscular systems. It helps to balance the Dhatu Vairagya. It controls over the different reflexes at the abdomin-visceral level voluntarily. The Dandi Dhatu specially increases the Urosepsis and adreno-cortical activity, which help to treat Asthma patients $[1,2]$. It decreases the secretion of free acids and increases the secretion of combined acid [4] and particularly all Dhatus help a lot to prepare a good basis for pranayama practice [5].

\section{References}

1. Ganguly SK (1982) Cardio-vascular Response to Yogic Treatment of Asthmatics. Yoga-Mimāmsā 20(4): 35-42.

This work is licensed under Creative Commons Attribution 4.0 License DOI: 10.19080/JYP.2019.07.555704
2. Karambelkar PV (1969) Uropepsin Excretion as influenced by Some Yogic Practices. Yoga-Mimāmsā 11(3): 9-14.

3. Gheranda Samhitā (1933) Adyar Madras. Theosophical Publishing House pp. 37-38 India.

4. Gharote ML (1976) Sodhan Kriyas-An Analysis. Yoga-Mimāmsā 18(3\&4): 68-78.

5. Digambarji Swāmi (ed) Hatha Pradipikā. Lonavla: Kaivalyadhām, II: 21, 22, 23, And 27.

6. Ganguly SK (1984) Official Souvenir. National Yoga Convention \& Championship Delhi.

7. Gharote ML (1975) Influence of Danda Dhauti on Gastric Acidity - A Preliminary Communication. Collected Papers on Yoga, Lonavla: Kaivalyadhām pp. 41-47.

Your next submission with Juniper Publishers
will reach you the below assets
- Quality Editorial service
- Swift Peer Review
- Reprints availability
- E-prints Service
- Manuscript Podcast for convenient understanding
- Global attainment for your research
- Manuscript accessibility in different formats
( Pdf, E-pub, Full Text, Audio)
- Unceasing customer service
Track the below URL for one-step submission
https://juniperpublishers.com/online-submission.php

